Volume 5 No. 1\&2 September 2007

\title{
REVIEW OF \\ SOUTHERN \\ AFRICAN STUDIES
}

A Multidisciplinary Journal of Arts, Social and Behavioural Sciences

A Journal of the Institute of Southern African Studies

(a) National University of Lesotho

(bil) Institute of Southern

African Studies 


\section{RN 305756 (ner ser..1)}

\section{REVIEW OF SOUTHERN AFRICAN STUDIES \\ A multidisciplinary Journal of Arts, Social and Behavioural Sciences}

\section{EDITORIAL BOARD}

$\begin{array}{ll}\text { E.M Sebatane } & \text { Pro-Vice Chancellor, NUL } \\ \text { F. Baffoe } & \text { Baffoe and Associates, Maseru } \\ \text { M. Mapetla } & \text { Ag Director, ISAS } \\ \text { T. Kebede } & \text { Head Documentation and Publications, ISAS } \\ \text { T. Petlane } & \text { Head Research, ISAS } \\ \text { E. Obioha } & \text { Department of Sociology and Anthropology, NUL } \\ \text { V.Z.Nyawo-Shava } & \text { Editorial Secretary }\end{array}$

Manuscripts and editorial correspondence, subscriptions and advertisement enquiries should be sent to:

The Publications Officer, Institute of Southern African Studies, National University of Lesotho, P.O. Roma 180, LESOTHO,

Prospective contributors should CONSULT THE GUIDE ON THE BACK COVER before submitting their manuscripts

(C) ISAS 2007

Annual Subscription:

African Institutions $\quad$ R60.00

Elsewhere $\$ 50.00$

Single Issues Africa R30.00

Elsewhere
MOTE

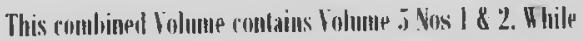

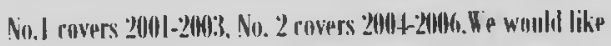
I0 assure you of the rounlarily of HeStS from lo date.

Thank vou for vaur rounlinued suppoirl

Published twice a year in January and June by the Institute of Southern African Studies.

ISSN $1024-4190$

Copy Edited by V.Z.Nyawo-Shava

Printed by Morija Printing Works, Lesotho

Typeset in ISAS by 'Mampho A. Macheli






\section{REVIEW OF SOUTHERN \\ AFRICAN STUDIES \\ A Multidisciplinary Journal of Arts, Social \\ Behavioural Sciences}

Vol. 5

No.1

Sept.2007

Articles

Page

Government Without Official Opposition: The Case of Lesotho 1993-1998

F.J.Likoti 1

Which Way Lesotho? Some Reflections on the Political Geography between Lesotho and South Africa V.Mashinini

Land Scarcity, Family Relocation and Settler-Host Community Relocations: The Experiences of Relocated Families in Mashinga and Mangochi in Southern Malawi P.Kishindo. 46

Poveerty, Gender and Education in Lesotho T. Makatjane

Experiences and Opinions of Economically Active Women on Violence Against Women: The Case of Selected Areas of work in Maseru

T.Makatjane and T.Mohasoa 89

Income Support for the Elderly in Zimbabwe A.C.Nyanguru 


\title{
GOVERNMENT WITHOUT OFFICIAL OPPOSITION: THE CASE OF LESOTHO 1993-1998
}

\author{
FAKO JOHNSON LIKOTI \\ Department of Politics and Administrative Studies. \\ National University of Lesotho \\ P.O. Roma 180. \\ Lesotho
}

\section{Abstract:}

From 1993 to 1998, Lesotho was governed without an official opposition in parliament. This situation destabilised the country's fragile democracy. The paper speculates that the country's stability, public policies and development programmes suffered adversely because of the problem of one dominant party governing alone. At the same time, the electoral system in Lesotho at the time was not able to reward losing parties, which gained less than 37 per cent of electoral support for opposition to be represented in parliament. Consequently, opposition parties engaged in concerted efforts to unseat the ruling party. Their efforts culminated in the unconstitutional removal of elected government by the King in 1994 and the incessant political instability in 1998, which led to the combined South African and Botswana military intervention in the country. The lack of opposition also prompted factionalism 
within the ruling party, ending with its fragmentation and the birth of LCD, which won the 1998 elections. Furthermore, the lack of opposition in parliament resulted in public policies not being adequately debated as the ruling party in 1993 and 1998 enjoyed concurrence from its members in parliament.

\section{Introduction}

Democratisation has been a major influence in Sub-Saharan Africa towards the end of the 1980s and early 1990s. According to Larr: Diamond (1995), what triggered this impetus was the demise of its historical rivals; fascism was virtually destroyed after second world war, the appeals of Marxism Leninism withered and experienced glaring economic failures, while military regimes lacked any ideological justification and legitimacy to govern as majority of citizens and international community pressed for formal guarantees of political and civil rights (Potter1997).

Lesotho could not resist these winds of change. Democratisation became inevitable, the military junta in Lesotho, though opposed to winds of change, had to submit to these forces. In 1993, Lesotho became a democratic country, after free and fair competitive elections were held. The election was, however, to usher in a period of uncertainty as the results failed to produce an official opposition in the 60-member parliament. Therefore, the "official opposition and formal opposition" terms will be used interchangeably to mean one and the same thing. It was this deficit within Lesotho political system that created instability within the Kingdom to date.

This paper analyses the 1993 and 1998 elections. By drawing on different democratic approaches the paper attempts to explain why these elections failed to produce an official opposition in parliament. Secondly, it discusses the relevance and importance of official opposition in parliament. It also reveals the problems that were encountered in Lesotho as a direct consequence of lack of opposition in parliament. Finally, the paper provides the road map 
as to what the Lesotho political elites should do in order to bring the situation to normality and promote democratic consolidation.

\section{The 1993 and 1998 Elections}

Finding itself under enormous international pressure to democratise the country, the military junta in Lesotho finally capitulated in 1993. On the $27^{\text {th }}$ March 1993, after a period of nearly 23 years without democracy in the Kingdom, general elections were held. The Basotholand Congress Party (BCP) swept the elections, taking all 65 seats. This landslide denied the opposition parties even a single seat in parliament (Molomo 1999). The scale of BCP victory was unprecedented in Lesotho history.

Shortly before 1998 elections, a new party, Lesotho Congress for Democracy (LCD) emerged from within the BCP. It was in this election (1998) that this party won 79 of the 80 constituencies leaving one to the opposition. While the Basotho National Party managed, by shear luck, to hold on to one seat. The LCD won 60 percent of the popular vote while the opposition collectively polled 40percent of the vote Molomo (1999). The following table illustrates the scale of opposition defeat from 1993 to 1999.

Table 1:Party Electoral Performance in 1993

\begin{tabular}{|l|l|l|l|}
\hline Contestants & No. of Votes & $\%$ of Votes & No. of Seats \\
\hline BCP & 398355 & 74.7 & 65 \\
\hline BNP & 120686 & 22.6 & 0 \\
\hline MFP & 7650 & 1.4 & 0 \\
\hline Other & 6287 & 1.2 & 0 \\
\hline Total & 532978 & 100 & 65 \\
\hline
\end{tabular}

Party Electoral Performance in 1998

\begin{tabular}{|l|l|l|l|}
\hline Contestants & No. of Votes & \% of Votes & No. of Seats \\
\hline LCD & 355049 & 60.7 & 79 \\
\hline BNP & 143073 & 24.5 & 1 \\
\hline BCP & 61793 & 10.6 & 0 \\
\hline
\end{tabular}




\begin{tabular}{|l|l|l|l|}
\hline MFP & 7460 & 1.3 & 0 \\
\hline Other & 16244 & 2.9 & 0 \\
\hline Total & 584740 & 100 & 80 \\
\hline
\end{tabular}

Source: (Roger Southall, 1993, 1994, 1998)

What was remarkable about both 1993 and 1998 election results was the absence of opposition in parliament. It was this situation that has characterised the current political system of Lesotho. The electoral system performs one of the most fundamental tasks in a representative democracy. For leaders to be elected, it is the electoral system that must play a crucial role of translating individual votes into seats in parliament Lijphart (2000). Lesotho inherited Single-Member Simple Plurality (SMSP), system from Britain in 1966. SMSP traces its birth during the early $18^{\text {th }}$ century Britain, before the establishment of the universal franchise, the birth of organised mass parties and pluralistic politics. It was during this period that the electoral system in operation in Lesotho was first used. In fact, when the system was introduced, it was then construed to have been;

appropriate for the pre-democratic and pre-industrial era when the function of parliament was to vote monies to the crown in return for local privileges and patronage, and local coteries of landowners and merchants elected one or two of their own to protect and enhance their wealth (Crewe, 1993:93).

Under this system, according to Lijphart (2000), each voter cast one vote and the candidate who accumulates most votes is declared a winner. Therefore, under this system of electing parliamentarians, each elector has only one vote; each constituency returns only one $\mathrm{MP}$; and the candidate who has more votes than any other becomes the MP regardless of whether he or she has more than 50 per cent of the votes cast in the constituency (Dearlove, 200:456). 
Supporters of this system do not attempt to defend it on the grounds of fairness but on the fact that it produces stable, responsible and moderate governments where MPs are closer to their constituents. While in some African countries, like Cameroon, Ghana and Nigeria, the electoral system has been able to produce opposition, in Lesotho the opposition has not been able to emerge through this system.

It is clear that electoral system does not meet popular expectations. Recent developments in Britain in 1997 indicated that, the system was modified. This was not the case in Lesotho during the above period. The country adopted the system in 1966 without even adapting it to suit the local conditions. In fact, the current signs indicate a shift in British perception in relation to the continuity of the model in British polity. In 1999, United Kingdom used proportional electoral model for both the state, local and European parliament elections. These are some of the strongest indications yet of the case to reform the system.

Despite the above general feeling that the electoral system has not helped Lesotho, some authors present a contrary view. Sekatle (1999) for example argues that it was misleading for some political scientists to cry foul that, the above electoral system (SMSP) denied opposition parties representation in parliament. The author contends that parties were represented in 1965 and they would have been represented again in the 1970 elections, had the BNP not annulled the elections. The fact of the matter is that, "the system rewards parties whose vote is concentrated locally and penalises parties whose support is evenly spread "(Crewe, 1993:93).

It would appear that BNP support is spread all over the country and therefore, the systems disadvantage against this party. The period of 23 years has changed the political landscape beyond the confines of SMSP. It does not follow that, because the parties were represented in 1965 and also that there were prospects of representation in 1970 that the same situation will arise again after 23yeas. May be if we had elections during the period between 1970 and 1993 we could have been forced to change the system. In fact 
SMSP is known to punish parties which obtain less than 37 percent of the total vote cast (Crewe, 1993)

For Southall (1999), the voters delivered a heavy punishment upon BNP for its long term of dictatorship. But, both these perceptions miss the crucial point as to why Lesotho electoral system, since 1993 has failed to produce an official opposition that might engender a fully representative system. Basotho continue to vote for BNP. In fact, BNP support base has increased as indicated in tablel above. The followers continue to attend public gatherings of this party. Why is it then, that, they persistently continue to do so if they are punishing the party? Is it the electoral system which is doing more punishing or the electorate? I will argue that, it is not the electorate but the electoral system which appears to exclude most small parties in Lesotho. What is becoming evidently clear is that, parties in this country have not been able to mobilise much support that can be accommodated by the current electoral system because of its exclusionary nature. Kadima (1999), arguing about the exclusiveness character of this model, contends that;

while agreeing with Sekatle that BNP's
confiscation of power in 1970 played a
part against it in1993, I nonetheless
believe that an electoral system that
ignores the choice of almost 40 percent
of the electorate is not inclusive enough,
and needs to be reformed to
accommodate significant (members of)
losing parties (Kadima, 1999;78).

He argues further that even the 1965 elections demonstrated exclusive patterns in that BNP won only 42 percent of popular vote, but it was over rewarded by 50 percent seats while other parties collectively polled 58 percent of votes and allocated only 48 percent of parliamentary seats. 
When one looks at the above electoral results, one realises that, the system, since the post-war era, has thrown up bizarre anomalies. This included rewarding wrong winners and granting of undue rewards as it did in 1951 when British Conservative party formed government after having won fewer votes than Labour, but more seats and, therefore, was able to govern Britain. In October, 1974, Labour won 39.2 per cent of the popular vote but 50.2 per cent of the seats (319 out of the 635), and 1983, the Conservatives won 42.4 per cent of the vote but 61.1 per cent of the seats (397out of 650 ) in Britain (Crewe 1993). The system which has been alluded to favouring large parties has failed in Lesotho to translate BNP electoral results both in 1993 and 1998 into parliamentary seats, and thus, making a mockery of Lesotho democracy. This has therefore, led to a country governed by one party, a feature which has created much political instability due to lack of opposition in the country.

\section{Democratic approaches}

In our quest to trace and explain patterns of democratisation in Lesotho, we need a set of ideas and explanatory generalisation related to some theoretical approaches. Some authors suggest associated characteristics which must prevail before a country can be said to be democratic. These are economic in nature, such as high gross national product, equally high education levels within the country, rapid industrialisation, urbanisation, individualistic culture, and a high degree of economic and social equality (Lipset $(1959,1983)$, Healey (1994).

In explaining democratisation, Lipset (1960), adopts a modernisation approach. He argues that, democracy could be related to a country's socio-economic development or level of modernisation. While several variables are considered, the level of development is critical. In fact, the more economically empowered people of the country are, on average, they are more likely to favour, achieve and maintain a democratic system of their country. A country, which boosts a high level of prosperity and economic 
growth, has a greater chance of democratic sustainability Lipset (1960).

The transitional approach challenges the Lipset modernisation for its functional perspective instead of asking how democracy comes into being in the first instance Rustow (1970). The propounders of this approach argue that, a holistic consideration from different countries as case studies provides a viable analysis other than embarking on functional requisites. They argue that, the actions of elites and their strategies during a country transition to democracy, is largely contingent on what they do when, how and where. Therefore, there is a clear distinction between initial democratic transition and democratic consolidation.

Conversely, the structural approach focuses on long-term processes of historical change. Therefore, democracy is explained by changing structures of power rather than by the agency of political elites. The interrelationships of certain structures of power such as economics, social and political, as they gradually change through history dictates and drives political elites and others along a long path towards liberal democracy (Potter, 1997).

It would appear that, these approaches have been unable to shed a light on the unique character of Lesotho political system, where there is no official opposition in parliament. This deficit, however, does not invalidate the importance of opposition in any democratic dispensation. There are several reasons why opposition parties are needed in democracies. This is because "the indispensable role of opposition parties in protecting the interests and rights of citizens, monitoring government, and consolidating democracy" (Habib and Taylor, 2000: 52) cannot be overemphasised. 


\section{The Relevance of Opposition to Stable Democracy}

The absence of official opposition means that national policies cannot be extensively debated. This system produces a parochial parliament whereby there is concurrence on all issues even where there are glaring problems because the side of the opposition which does not exist in parliament cannot be known. Therefore, an opposition as a minority representative in parliament opposes the majority and presses for alternative solution, hence using influence to derive a viable compromise. It is generally agreed that a structured opposition is a viable and sustainable part of a democratic polity. The absence of opposition in Lesotho means that, the question of checks and balances in parliament cannot be attained.

In the British political system, one minority party exercises the function of political opposition to the government, most importantly scrutinising government policies and providing alternative course of direction. There is recognition of the formal function of opposition as highlighted by the ingenious notion of His Majesty's Opposition and allowing opposition to the government while remaining loyal to the King. The opposition, therefore, becomes a shadow government, a measure that forces it to remain loyal to the King.

Political opposition, on the other hand, in the British political system and, above all, formal opposition remained a vividly salient notion of British polity. Several authors insist that political opposition should not only be considered in the narrow framework of minority/majority relations but that set of reference should include more core elements of the political system whereby the political opposition have the main function of representing the contingency of the public domain. Neunreither (1998) argues that, the government presents a policy conjecture and the opposition demonstrates that you could arrive at different conclusion using the same data.

Neunreither submits further that, the main function of the official opposition is to provide for an alternative within the 
system. In this discussion, official or formal opposition means a political party with less seats in parliament as opposed to the majority party, which governs the country with large number of seats in the National Assembly.

While there are many definitions of democracy, there is a consensus among scholars that "a democracy can almost be defined in terms of the existence of an effective opposition because without these opposition parties" (Shrire, 2000:27), democratic consolidation cannot be achieved. Habib and Taylor quoted Jun and Ian Shapiro (1995) who argued that opposition parties:

...facilitated a peaceful alteration in government. Parliamentary parties are perceived as institutional sites where 'counter political elites... (can) organise and inform themselves so as to be able to contest for power' (Ibid, 272). Should such institutional sites not exist, 'crises for the government are correspondingly more likely to become crises for the democratic regime.(Ibid)' This then underlines their second argument, that a parliamentary opposition ensures that a citizenry's unhappiness with government is not automatically translated into a delegitimation of the democratic order (Habib Adam and Taylor Rupert., op cit,52.).

Opposition parties provide a viable institutional outlet for people who are unhappy with the government performance. It is through these institutions that government is kept in check. Therefore, opposition parties present a constant reminder to the government that if its performance is not up to standard they would be removed from power come the next elections. By sustaining their attack on 
the ruling party, enables the opposition parties to be perceived by prospective voters as a viable alternative to the ruling party.

Furthermore, it can be argued persuasively that "a viable parliamentary opposition facilitates institutional arrangements that enable the performance of a variety of public interest functions"(Ibid,52). In most cases, the opposition has an interest in keeping the government on its toes because this will make prospective voters see them as a better alternative to the government. By consistently engaging the government, the opposition parties are able to monitor and hold the government to account in a way that an ordinary citizen could not because they ask awkward questions both inside and outside parliament. They are also able to expose corrupt practices and excess of government. The absence of opposition in the legislature is fraught with severe consequences for both sustainable democracy and the national stability. It is these problems that we now turn to.

\section{The problems of governing without official opposition}

The dominance of $\mathrm{BCP}$ in parliament contributed to the rise of party functionalism and the eventual break-up of Basutoland Congress Party. Had there been an official opposition in Lesotho after 1993 election, events that led to the break-up of BCP could have been avoided. Inevitably, factionalism, which afflicted the party with more vigour than before, prevailed. This situation was exacerbated by BCP winning all sixty-five (65) parliamentary seats. Therefore, a power struggle between the factions ensued in earnest at all levels of the ruling party. (Pule; 1999).

The presence of an opposition party could have, indeed, benefited the BCP because its members of parliament were going to be forced to bury their differences and forged party unity and consensual decision-making. Convergence of interests could have been promoted by a relative level of party homogeneity within the BCP parliamentarians. The parliamentary machinery was rendered moribund and ineffectual as power struggle between the party factions intensified. In one incidence regarding the election of 
deputy speaker, on the $26^{\text {th }}$ July 1996 , the other faction staged a walkout in parliament claiming unparliamentary procedure was followed in selecting the Speaker of parliament. They argued that, the matter should have been discussed by BCP parliamentarians prior to its implementation. This squabbling paralysed the national parliament dominated by one party. This chain of events made a mockery of the parliament. In fact, some of the most important development programmes could not be debated properly because of lack of opposition in parliament. The Lesotho Highlands Water Development Fund was a glaring case in point.

What emerged, as a viable development scheme, from the Lesotho Highlands Water Development Fund, became a watershed for Lesotho politics. Initially, the World Bank had insisted that this fund should not interfere with the Bank austerity measures being implemented by the Lesotho government rather channelled directly into social development.

This fund became popularly known in both public and government circles as

"Fato-Fato" (Meaning; scratch-scratch without altering the surface). The whole programme was a fiasco as it failed to translate its objectives of trickling down to the common man on the street into tangible and desirable results. It became a vehicle for parliamentary enrichment. The funds were completely misappropriated by parliamentarians. The situation deteriorated into an elaborate corruption patronage scheme designed to benefit the party faithful at constituency level. It would appear that members of parliament who were afflicted by parliamentary parochialism appropriated these funds to cement their popularity at their rural base (Selinyane, 1996, Pule (1999).

The evidence of blatant misappropriation by parliamentarian was presented succinctly by the then Finance Minister in his 1996/97 Budget speech. He argued that:

there have been incidences of members

of parliament being in possession of

fund moneys an action specifically 
prohibited under Finance Act, as fund resources are public funds and government is accountable to the public through parliament. Instances of Members of Parliament becoming directly involved in decisions concerning the implementation of projects (Pule, 1999:15).

Despite the Minister's protestations, it was still difficult to hold the parliament accountable, since in the nature of things an official opposition that was lacking in parliament can assume this role. It is the function of the opposition to hold the government in check and accountable for the above rampant misuse of public funds. Unfortunately, in the case of Lesotho political system, there was a great deficit in this direction. The elite corruption became too elaborate; knowing clearly that the opposition. which exists outside parliament, was powerless to force the government to account. Instead, the pattern that emerged was that this problem fuelled ammunition within the ruling party factions not to force another group to account but to demand more of the cake themselves.

The problems of governing without official opposition in Lesotho have ushered a new dimension, that of government failure to present the nation with the balance sheet, which reflect how public monies have been used. This issue of public expenditure remains shrouded in secrecy. This pattern created much concern within Lesotho political circles. It was nearly five years since the last audit report had been published. Since there was no opposition in the then parliament, there was nobody to press for the publication of this crucial report that will inform the public about the current status of government expenditures. In fact, what is even more alarming is that under the Constitution of Lesotho, the Auditor-General $(\mathrm{AG})$ is mandated to produce this report once a year. It goes further to argue that, $A G$ shall ensure that all moneys disbursed by parliament are utilised for the purposes intended. Therefore, Section 117 (2) (b) states that: 
at least once in every year $(A G)$ is to audit and report on the public accounts of the government of Lesotho, the accounts of all officers and authorities of that government, the accounts of all courts in Lesotho, the accounts of every Commission established by this Constitution and the accounts of the Clerk to each House of Parliament (the Constitution of Lesotho, 1993,104).

The complete disregard of this Constitutional section is indicative of how far governments governing without official opposition can go in defeating democratic principles of transparency and accountability.

On the $22^{\text {nd }}$ September 1994, the government of Lesotho reached an agreement with the Lesotho Teachers Trade Union (LTTU). This agreement was in relation with the revision of teacher's salaries. The government compensation policy that was drawn after protracted negotiations with the teachers entails that teachers' salaries would be reviewed and salary increment shall come to force from February 1995. However, the measure was implemented for only two months from February until March before a dramatic policy "U-turn " by the government. According to Lentsoe La Basotho newspaper (1995), a parliamentary speech was made on the $12^{\text {th }}$ March 1995, which reflected the agreement as a mistake and called for its immediate termination. Since there was no official opposition in parliament to pressure the government to account for this dramatic policy change, the government reneged on the agreement with LTTU unhindered. It proceeded freely to terminate this measure unilaterally without even engaging the concerned bodies. This undemocratic move, which was motivated by the absence of opposition in parliament, was to unleash one of the incessant and protracted strikes ever seen in the country. The government response was swift on the strikers. It announced a "no work no pay" policy against the striking teachers. The government 
did not even explain their stance to the nation clearly. It just continued as if nothing had happened.

Lesotho experienced unprecedented levels of political instability immediately after 1993 election. For the first time in the political history of Lesotho, the country witnessed a military uprising. This culminated into an open warfare between the two main army barracks based in Maseru Township at Makoanyane and Ha Ratjomose. It would appear that there was a simmering discontent within the Army, which the government was unable to ameliorate. Since there was no opposition in parliament, the government could not be held to account. There was no satisfactory explanation from the authorities relating to what was the real source of the problem. Because of the long period of authoritarian rule in Lesotho, civil society was still in its infancy, therefore, appeared very weak to tackle the government head on for its invasiveness relating to this military disturbance.

Political parties, which were not in parliament protested. They demanded, among others, that the King should intervene and dissolve the government. They presented their memorandum at the Royal palace. The King immediately and unconstitutionally dissolved the government. This action unleashed incessant instability in Lesotho which motivated foreign intervention and led to the signing of " the 1994 Memorandum of Agreement that reinstated the then $\mathrm{BCP}$ government after a temporary displacement by the King which was overseen by Botswana, South Africa and Zimbabwe" (Matlosa, 1999;189).

These problems reached fever pitch after 1998 general election, which failed to produce an official opposition. The 1993 election was equally destabilising but the conflict that erupted in 1998 far surpassed ordinary Mosotho expectations. The opposition parties were ostensibly crying foul about election returns. On the $4^{\text {th }}$ august 1998, opposition political parties intensified their demonstrations and appealed to The King to intervene and disband the government, declare the elections null and void, and call for fresh elections under the auspices of a government of National Unity. The party that had won the election (LCD) in tablel argued 
that the elections were free and fair. The International observers further reiterated these sentiments. They argued that the elections were characterised by demonstration of freedom and fairness.

However, the fundamental problem was the conspicuous absence of the opposition in parliament as reflected in table 1 above. The situation was highly charged. Protesters camped at the palace gates, demanding The King's intervention. This situation which was created by opposition parties, culminated in the complete breakdown of the rule of law. The government was paralysed as both the army and the police failed to dislodge the protesters from the palace grounds. A state of anarchy ensued.

These events were terminated by South African Defence force intervention on the $22^{\text {nd }}$ September 1998 , which came to restore order on the invitation of the government. Following the protracted crisis, the government governing without opposition reneged on the ongoing negotiations between political parties and defied all rules in Lesotho and requested external military intervention. Not even The King was notified about this unconstitutional move. In fact, the constitution of Lesotho section 92 states thus:

The King shall have the right to be consulted by the Prime Minister and other Ministers on all matters relating to the government of Lesotho and the Prime Minister shall keep him fully informed concerning the general conduct of the government of Lesotho and shall furnish him with such information as he may request in respect of any particular matter relating to the government of Lesotho"(The constitution of Lesotho, 1993,88).

Both the King and all parties outside parliament were not consulted about the intervention. This intervention according to Matlosa (1999), not only failed to establish its legal intention but failed to 
meet the necessary statutes of the UN charter, especially, chapter VI, VII and VIII. Furthermore, the intervention did not get the blessing of all protagonists, hence the reasons why the levels of causalities became too high.

Matlosa (1999) argues further that the intervention did not even have a clear mandate from both the organisation of African Unity $(\mathrm{OAU})$ and SADC. In fact, even the 1994 guarantor status given to Botswana, South Africa and Zimbabwe did not even have a military intervention clause. These countries felt compelled by the on going lawlessness to intervene to restore law and order. The whole question was a further illustration of dangerous prospects that any country will be confronted with when governed by one party without the official opposition and deciding on crucial national matters without informed debate from the other side. To ameliorate the situation, SADC provided a political settlement, which saw the establishment of Independent Political Authority (IPA), composed of all registered parties, in the country to restrain the ruling party. The IPA disallowed the ruling party to have free reign over the preparation of the next election. The IPA was mandated to perform the following tasks: to

prepare, in liaison with the legislative and executive organs of the state, for a fresh election in the year 2000. level the playing field for all parties and candidates to participate meaningfully in the election in an environment that promotes and protects human rights, eliminate any impediment to legitimate political activity, including undue victimisation or intimidation; and ensure equal treatment of all political parties and candidates by all government-owned media, prior to and during the election (Matlosa, 1999; 190).

It was clear that no party can level the political field on its own, instead must work with other parties. It would appear that the establishment of IPA under this political settlement was 
precipitated by direct result of not having an official opposition in parliament.

\section{The prospects for democratic consolidation in Lesotho}

For democracy to be sustainable, all sides within the political system must have representation. This means that the loser's voice must be entertained. This was not impossible to attain in Lesotho political system. What is required is the political will of all role players to inculcate, nourish, entrench a culture of tolerance and political accommodation. The must be a clear recognition by all political leaders that the ruling party and opposition parties need each other for nation-building and national unity. There is a strong base for this to take root. Lesotho is blessed with one homogeneous ethnic group. Unlike other ethnic-ridden countries in Africa, Lesotho problems could be solved with relative ease between the parties and thus creating the much-cherished Lesothoness. It is this potential which must be taped and positively directed through national dialogue to achieve the political stability which the country needs desperately.

In order to address the question of democratic sustainability, the parties must recognise and accept that a win-win solution rather than zero-sum solutions are best for Lesotho's future. They must adopt constructive resolution and management of conflicts without recourse to violent confrontation by belligerent parties.

The rules of the game should be clearly established. Politics is about contesting power. In the absence of a long-standing constitutional tradition, rules and their application must be negotiated. It is imperative that the parties should adopt a broadly representative and inclusive electoral system that is able to accord the ruling party the needed legitimacy and opposition parties a recognisable political role in national affairs. The more people are excluded from their national affairs the more the country stability is affected.

The governance without official opposition is fraught with dangers. What Lesotho must seriously consider, is the adoption of 
proportional representation model. This system strives for a wider representation and limits any prospects for any political party to govern without opposition. The current efforts must be intensified which are geared towards the changing of the current majoritarian system in order "to increase representation for non-winning parties and ultimately limit the incidence of election-related conflicts"(Akokpari: 1998:77).

\section{Conclusion}

What is evident is that Lesotho has not derived dividends from the political system characterised by exclusionary practices. The electoral system has not been successful in ushering opposition party in parliament and promoting stability in Lesotho following the history of acrimony on its outcome since 1993. The system has become ineffectual to say the least. The British have modified the system and South Africa has adopted a more embracing electoral system why can't Lesotho do the same? It is more prudent to jettison this situation and adopt a system that shall provide Basotho with Opposition in parliament and better proportional representation on national affairs.

What has become clear in Lesotho is that the absence of opposition has presented the country with severe problems. These problems are mainly policy oriented. In fact, the fundamental ingredient of democracy is the participation of electorates in public policy through their representatives, this aspect is lacking and it has made a mockery of democracy in this country. As such, the government has forgotten to consult stakeholders in all aspects of public policy. The Auditor's report was not issued for some years to inform the nation about the current status of government expenditure. This is another serious democratic deficit. It is clear that a country governed without opposition will always remain unstable and Lesotho is a case in point.

This will ameliorate the current situation whereby the government is having a free reign in national affairs without having 
to debate crucial policies with the official opposition and thus rendering Lesotho infant democracy moribund. Therefore, there is a need to deepen and consolidate Lesotho's democracy and political stability, in order to lay the foundations for development; and boosting of Lesotho's international image as a widely accepted beacon of peace, stability and tolerance and thus a model for other war-torn societies to emulate.

\section{BIBLIOGRAPHY}

Akokpari, J. "Democratic Stability in Lesotho" Lesotho Social Science Review Vol.4 (2) December, 1998. 65-82.

Birch, H.A. (1996). The Concepts and Theories of Modern Democracy. London: Routledge.

Crewe, I. "Parties and Electors" in Budge I. et al ( $3{ }^{\text {rd }}$, ed), (1993). The Developing British Political System: The 1990s. London: Longman.

Cutright, P. (1963). "National Political Development: Measurement and Analysis" American Sociological Review $28,(2) .253-64$.

Danziger, J.N. $\left(4^{\text {th }}\right.$, ed $)$, (1998). Understanding the Political World: A Comparative Introduction to Political Science. England: Longman.

Dearlove, J. et al ( $3^{\text {rd }}$, ed), (2000). Introduction to British Politics. Cambridge, Polity Press.

Dennock, J.R. (1974). Democratic Political Theory. Princeton, NJ: Princeton University Press.

Diamond, L. et al (2 ${ }^{\text {nd }}$ ed), (1995). Politics in Developing Countries: Comparing Experiences with Democracy. London: Lynne Riener Publishers.

Habib Adam and Taylor Rupert. Political Alliances and Parliamentary Opposition in Post-Apartheid South Africa: In Conference on 'Opposition in South Africa's New 
Democracy'. Hosted at Kariega Park in the Eastern Cape, 28-30 June 2000.

Hadenius, A. (1992) Democracy and Development Cambridge University Press.

Healey, J. et al (1994). Democracy, Governance and Economic Policy: sub-Saharan Africa in Comparative perspective Britain: Overseas Development Agency.

Jung Courtney and Shapiro Ian, South Africa's Negotiated Transition: Democracy, Opposition and the New Constitutional Order, Politics and Society Vol.23, No3 (1995). 269-308.

Kadima, D. "The DRC and Lesotho Crisis: Some Lesson for SADC", Lesotho Social Science Review Vol.5 1. June 1999. 65-82.

Lentsoe la Basotho, Maseru $12^{\text {th }}-18^{\text {th }}$ August 1995.

Liebman, S.C. (1997). Religion, Democracy and the Dilemma of Social Order: In Shain, Y. et al (1997) (ed) Democracy: The Challenges Ahead Great Britain, Macmillan Press LTD.

Lijphart, A. (2000). Electoral Systems and Party Systems: A study of Twenty-Seven Democracies, 1945-1990. Oxford University Press.

Lipset, S.M. (1960). Political Man London, Heinemann.

(1959)"Some social requisites of democracy: economic development and political legitimacy": The American Political Science Review 53,1:69-105.

(1983). Political Man: The social Bases of Politics. London: Heinemann.

Matlosa, K. "Conflict and Conflict Management: Lesotho's Political Crisis After the 1998 Election" Lesotho Social Science Review Vol.5 1 June 1999. 163-196.

Molomo, M. "External Military Intervention in Lesotho's Recent Political Crisis" Lesotho Social Science Review Vol.5.1 June 1998. 133-162.

Nelson, B. (1974). The Nature of Democracy. Great Britain. Thomas Nelson and Son LTD. 
Neureither, K. (1998). "Governance without Opposition: The Case of The European Union" Government and Opposition Vol 33, 1. 399-441.

Potter, D. et al, (ed). (1997), Democratisation. Cambridge, Polity Press.

Pule, N. "Power Struggle in the Basutoland Congress Party" Lesotho Social Science Review, 5(1) 1999 .1-30.

Rudebeck, L. $\left(4^{\text {th }}\right.$, ed $),(1992)$. When Democracy Makes Sense: Studies in the Democratisatic Potential of Third World Popular Movement Sweden: Uppsala University, Akut.

Rustow, D. (1970). "Transition to democracy" comparative politics, Vol2, .337-63.

Sancton, T.A. (1987). "Democracy's fragile flower spreads its roots" Time 130, 28:10-11.

Sekatle, P. (1999)."The Political Dynamics of the 1998 Elections in Lesotho". Paper prepared for the SAPES Regional Conference on the Crisis and Intervention in Lesotho, Maseru, $5^{\text {th }}-6^{\text {th }}$ February 7 .

Selinyane, N.P. (1996). "Continuity and Change in State-Social Relations in Rural Lesotho: A Critical Astorical Analysis," Faculty of Humanities Seminar Paper Presented at the Institute of Southern African Studies National University of Lesotho, $28^{\text {th }}$ November.

Shrire, Robert. The Realities of Opposition in South Africa: Legitimacy, Strategies and Consequences: In Conference on 'Opposition in South Africa's New Democracy'. Hosted at Kariega Park in the Eastern Cape, 28-30 June 2000, 27. Southall, R. Is Lesotho South Africa's Tenth Province? In Lesotho in Crisis: Managing Conflicts in Southern Africa," Foundation for Global Dialogue, Johannesburg, March 1999, P21.

'The 1993 Election; Review of African Political Economy Vol. 21.59 (1994). 110-118. 
Southern African Report, Vol.14.1 (1998). 12-17; Independent Electoral Commission (IEC), Provisional Results, May 27, 1998.

The Constitution of Lesotho $25^{\text {th }}$ March 1993.

Vanhanen, T. (1997). Prospects of Democracy: A Study of 172 Countries. London: Routledge 


\section{(c) 1 (i) (9)}

This work is licensed under a

Creative Commons

Attribution - NonCommercial - NoDerivs 3.0 License.

To view a copy of the license please see:

http://creativecommons.ora/licenses/bv-nc-nd/3.0/

This is a download from the BLDS Digital Library on OpenDocs

http://opendocs.ids. ac.uk/opendocs/ 